\title{
ASSESSMENT OF WATER QUALITY INDEX OF GROUNDWATER RESOURCES IN IWO LOCAL Government Area, OSUn State, SOUTHWESTERN NiGERIA
}

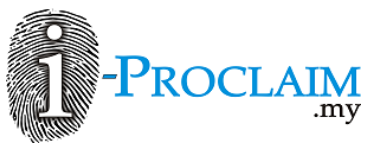

Asia Pac. j. energy environ.

\section{Y. O. Adetona*, K. T. Oladepo}

Department of Civil Engineering, Obafemi Awolowo University, Ile-Ife, 220282, Osun State, NIGERIA

*Email for Correspondence: yoadetona@pg-student.oauife.edu.ng

This study assessed the groundwater quality of 30 selected wells and boreholes in Iwo Local Government Area, Osun State, Nigeria. Groundwater sources were randomly stratified and identified according to the 15 political wards using hand-held GPS equipment. The selected sources were sampled during rainy season (October) and dry season (January) to determine water quality. The physico-chemical and microbiological parameters of the water samples such as temperature, turbidity, total suspended solids, $\mathrm{pH}$, electrical conductivity, total dissolved solids, total alkalinity, total hardness, chloride, sulphate, nitrate, phosphate, magnesium, calcium, iron, zinc, lead, manganese, cadmium, chromium and total coliform were determined using standard methods. The results showed that total hardness, calcium, cadmium, sulphate and phosphate had mean values above the acceptable values for rainy and dry seasons; their mean values in $\mathrm{mg} / \mathrm{l}$ for rainy season were 252.933, 98.267, 0.018, 305.119 and 1.762, respectively, while their values for dry season were 299.633, 115.831, 0.020, 285.695 and 1.705, respectively. The Water Quality Index (WQI) values showed that $30 \%$ of the selected groundwater sources were fit for consumption while $60 \%$ were poor and $10 \%$ were unfit for drinking during rainy season. During the dry season, $50 \%$ of the groundwater sources were fit for consumption, $40 \%$ were poor and $10 \%$ were unfit for consumption.

Key words

Contamination, groundwater, water supply, quality, treatment

This article is is licensed under a Creative Commons Attribution-NonCommercial 4.0 International License.

Attribution-Non Commercial (CC BY-NC) license lets others remix, tweak, and build upon work non-commercially, and although the new works must also

acknowledge \& be non-commercial.

\section{INTRODUCTION}

Water is basic for the survival of every living thing. It is also vital for the world's economic and industrial developments. The world's population grows quickly in both developed and developing countries. This makes water an essential and valuable asset. It is needed domestically for drinking, agriculturally for irrigation and industrially for the production of goods. It is essential to check the quantity and quality of water aimed at residential, agricultural and industrial purposes. WHO, (2017) stated that the provision of potable water is part of the Sustainable Development Goals (SDGs).

There are two major sources of water supply. These include both groundwater and surface water. The groundwater plays a very significant role in meeting the ever-increasing water demands from the residential, agricultural and industrial regions. This role necessitates technological efforts, particularly through the erection of wells and boreholes, both of which are derived from underground water. Surface water requires more treatment operations for its portability because it gets contaminated easily due to increasing urbanization (Dohare et al., 2014). Nas (2009) reported that a shortage of supply of quality surface water due to rapid industrialization and population has amplified groundwater usage. 
Recently, these groundwater sources are under the risk of degradation in both quantity and quality in many parts of the world, especially Nigeria. Large quantities of human and industrial wastes are discharged into the environment, which causes a serious threat to the groundwater (Adegbola and Adewoye, 2012). These wastes infiltrate into the groundwater gradually and their concentrations are enhanced with continuous discharge, coupled with some other environmental factors. Munna et al., (2015) reported that excessive pumping and unscientific management of aquifers are also accountable for the deterioration of groundwater quality.

Generally, contaminations in built-up areas of Nigeria are anthropogenic. This is as a result of discharged effluents and untreated wastes, especially in Osun State, Nigeria (Atobatele and Olutona, 2013; Jeje and Oladepo, 2014). Menaces from water-borne diseases are obviously public health distress in Iwo Local Government Area (Ogunbode et al., 2016). Water supply for domestic and industrial use should be free from disease-causing organisms and other matters which are unacceptable to the final consumers. This is because contaminated groundwater makes a negative impact on public health (Sharma and Chhipa, 2013). In order to safeguard the public health, rigorous sampling and analysis of groundwater samples to assess water quality represent the major purpose of a monitoring program (Ahmed, 2017). The measurement of the type and level of contaminants present in a sample is generally referred to as water quality assessment.

Water quality index is an essential tool used to derive information about the quality of any source of water supply (Herojeet et al., 2016). It is a technique which derives a simple index by summarizing various groundwater quality parameters and serves as a useful tool in water quality management and control. The highly recommended water quality index established by various agencies and departments are the Washington State Water Quality Index, Taiwan Water Quality Index, Canadian Water Quality Index, Colombia Water Quality Index, Florida Stream Water Quality Index, French Creek Quality Index, France Water Quality Index, Malaysian Water Quality Index, Oregon Water Quality Index and British Colombia Water Act Quality Index (Mahapatra et al., 2012).

\section{Materials AND METHOdS}

\section{Study Area}

Iwo Local Government Area is one of the 30 Local Government Areas in Osun State, Nigeria. It is divided into five quarters namely; Isale Oba, Molete, Oke Adan, Gidigbo and Oke Oba (Ogunbode et al., 2016). These are further subdivided into 15 political wards. The local government encompasses rural, agricultural and urban regions. The urban region forms Iwo town, which is located on Latitude $07 \mathrm{o} 38^{\prime} \mathrm{N}$ to $07040^{\prime} \mathrm{N}$ and Longitude $004009^{\prime} \mathrm{E}$ to $004 \mathrm{o} 11^{\prime} \mathrm{E}$.

Iwo is the administrative headquarter town of Iwo Local Government Area of Osun State in the Southwestern geopolitical zone of Nigeria. The town has an area of $245 \mathrm{~km} 2$ with a population of 191,348 of Yoruba descent and predominantly Muslims (National Population Commission, 2006). It is a nodal town from which towns such as Ibadan, Ile-Ogbo and Ede can readily be accessed. However, the study area shares boundaries with Aiyedire and Ola Oluwa in Osun State. It also shares boundaries with Lagelu, Akinyele, Afijio and Oyo East in Oyo State as shown in Figure 1. The study area is endowed with two rivers namely river Oba and river Aiba. River Aiba can be located at the north-eastern part of the study area, which was dammed and named Aiba reservoir for public water supply.

Aiba reservoir can be located between longitude 4o11' to 4o 13' East of the Greenwich and latitude 7o 38' to 7o 39' North of the Equator. It is a man-made lake located in Iwo city in the southwestern part of Nigeria. Aiba water reservoir located within government forest reservation area in the town serves as the major source of potable water in Iwo. Unfortunately, there is an inadequate supply of potable water from the waterworks, due to poor management and an increase in the population of the area. This led to the exploitation of underground water sources in the town.

The mean annual rainfall varies from $150 \mathrm{~cm}$ in the southern part of Nigeria to $300 \mathrm{~cm}$ (Ogunbode et al., 2016; Olutona et al., 2012). Mean maximum ambient temperature values range between $33.84 \mathrm{oC}$ in February and $28.8 \mathrm{oC}$ in August, while mean minimum temperatures range between $25.18 \mathrm{oC}$ in March and $23.0 \mathrm{oC}$ in August. Higher temperatures are mostly recorded at the peak of the dry season, while lower temperatures are recorded in the rainy season.

\section{Collection of Samples}

Water samples were collected for water quality and bacteriological studies from 30 locations including boreholes, hand pump and shallow wells within Iwo Local Government Area as shown in Table 1. The sampling was designed to target the population demanding groundwater majorly for domestic purpose. 

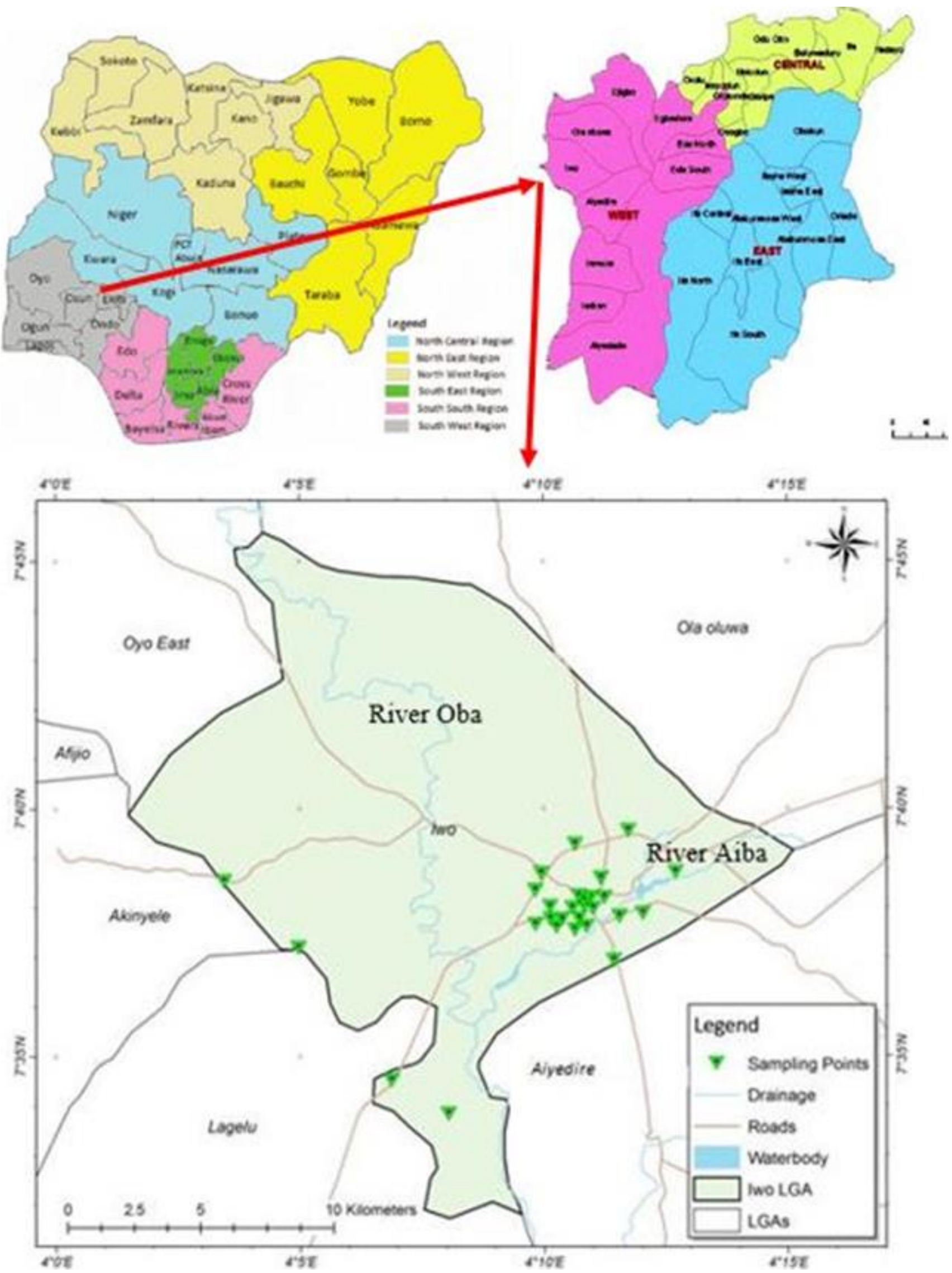

Figure 1: Map of the Study Area 
Table 1: Locations of selected hand pump boreholes, boreholes and shallow wells within Iwo Local Government Area

\begin{tabular}{|c|c|c|c|c|}
\hline $\mathrm{S} / \mathrm{N}$ & Political ward & Latitude & Longitude & $\mathrm{GL}(\mathrm{m})$ \\
\hline 1 & Isale Oba Ward 01A & $07^{0} 37^{1} 32.6^{11}$ & $04^{0} 10^{1} 38.7^{11}$ & 237 \\
\hline 2 & Isale Oba Ward 01B & $07^{0} 37^{1} 46.6^{11}$ & $04^{0} 10^{1} 43.9^{11}$ & 249 \\
\hline 3 & Isale Oba Ward 02A & $07^{0} 37^{1} 37.2^{11}$ & $04^{0} 10^{1} 52.7^{11}$ & 237 \\
\hline 4 & Isale Oba Ward 02B & $07^{0} 37^{1} 45.5^{11}$ & $04^{0} 10^{1} 22.5^{11}$ & 249 \\
\hline 5 & Isale Oba Ward 03A & $07^{0} 37^{1} 52.7^{11}$ & $04^{0} 12^{1} 02.2^{11}$ & 245 \\
\hline 6 & Isale Oba Ward 03B & $07^{0} 37^{1} 49.2^{11}$ & $04^{0} 11^{1} 33.4^{11}$ & 242 \\
\hline 7 & Isale Oba Ward 04A & $07^{0} 37^{1} 36.5^{11}$ & $04^{0} 10^{1} 15.8^{11}$ & 241 \\
\hline 8 & Isale Oba Ward 04B & $07^{0} 36^{1} 55.6^{11}$ & $04^{0} 11^{1} 26.4^{11}$ & 242 \\
\hline 9 & Molete Ward 05A & $07^{0} 37^{1} 58.8^{11}$ & $04^{0} 11^{1} 01.3^{11}$ & 250 \\
\hline 10 & Molete Ward 05B & $07^{0} 38^{1} 02.4^{11}$ & $04^{0} 10^{1} 49.6^{11}$ & 259 \\
\hline 11 & Molete Ward 06A & $07^{0} 38^{1} 11.7^{11}$ & $04^{0} 11^{1} 14.8^{11}$ & 246 \\
\hline 12 & Molete Ward 06B & $07^{0} 38^{1} 42.5^{11}$ & $04^{0} 12^{1} 42.5^{11}$ & 254 \\
\hline 13 & Molete Ward 07A & $07^{\circ} 38^{\prime} 35.0^{\prime \prime}$ & $04^{\mathrm{o}} 11^{\prime} 10.9^{\prime \prime}$ & 260 \\
\hline 14 & Molete Ward 07B & $07^{0} 38^{1} 35.1^{11}$ & $04^{0} 11^{1} 10.8^{11}$ & 260 \\
\hline 15 & Oke Adan Ward 08A & $07^{0} 38^{1} 10.6^{11}$ & $04^{0} 10^{1} 54.7^{11}$ & 249 \\
\hline 16 & Oke Adan Ward 08B & $07^{0} 38^{1} 12.0^{11}$ & $04^{0} 10^{1} 57.5^{11}$ & 255 \\
\hline 17 & Oke Adan Ward 09A & $07^{0} 38^{1} 08.7^{11}$ & $04^{0} 10^{1} 50.2^{11}$ & 253 \\
\hline 18 & Oke Adan Ward 09B & $07^{0} 38^{1} 13.9^{11}$ & $04^{0} 10^{1} 43.3^{11}$ & 252 \\
\hline 19 & Oke Adan Ward 10A & $07^{0} 39^{1} 16.4^{11}$ & $04^{0} 10^{1} 38.9^{11}$ & 269 \\
\hline 20 & Oke Adan Ward 10B & $07^{0} 39^{1} 32.9^{11}$ & $04^{0} 11^{1} 44.3^{11}$ & 255 \\
\hline 21 & Gidigbo Ward 11A & $07^{0} 37^{1} 45.7^{11}$ & $04^{0} 10^{1} 08.3^{11}$ & 243 \\
\hline
\end{tabular}

Therefore groundwater sources were randomly stratified and identified according to the 15 political wards using handheld Global Positioning System (GPS) equipment. Most of the wells were covered in the urban region, while those located in rural regions were unlined and hand pump wells. The location of each well was recorded using a handheld GPS. Sampling was done once during the rainy season (October) and also once during the dry season (January).

\section{Analysis of Water Samples}

The 21 physical, chemical and microbiological parameters such as temperature, turbidity, $\mathrm{pH}$, electrical conductivity, total suspended solids, total dissolved solids, total alkalinity, total hardness, chloride, sulphate, nitrate, phosphate, magnesium, calcium, iron, zinc, lead, manganese, cadmium, chromium and total coliform were selected in line with researches carried out by Ogunbode et al., (2016) and Olutona et al., (2012).

The $\mathrm{pH}$ of water samples were measured in-situ, using a $\mathrm{pH}$ meter. Temperature was measured at the sampling points using a mercury thermometer with an accuracy of $0.1{ }^{\circ} \mathrm{C}$, at $25{ }^{\circ} \mathrm{C}$. Electrical conductivities of the water samples were determined using platinum electrode conductivity meter. Total dissolve solid was determined by using total dissolved solid meter. The quantity of chloride present in the water samples was determined by titration using standard silver nitrate. Hardness was determined by standard Ethylene Diamine Tetra-acetic Acid (EDTA) titration method.

Sulphate, nitrate and phosphate concentrations of the water samples were determined using UV-Spectrophotometer. Complexometric titration method was used to find the quantity of calcium of the hardness of water by titrating the water sample with a standard EDTA of known concentration and volume. Magnesium was determined by calculating the difference between total hardness and calcium hardness as $\mathrm{CaCO}_{3}$ equivalent. The result was multiplied by mass ratio of magnesium (0.243).

The alkalinity of the water samples were determined by titrating $100 \mathrm{ml}$ of the samples with $0.2 \mathrm{~N}$ solution of sulphuric acid using phenolphthalein and mixed indicators as indicators. Total suspended solid was measured gravimetrically after drying in an oven at $105^{\circ} \mathrm{C}$ and cooled to room temperature in a desiccator. Electronic turbid meter with scatteredlight detectors was used for turbidity measurement after calibrating the instrument with distilled water.

The total coliform in the water samples were obtained using the membrane-filtration method. The heavy metals in the samples were analyzed using Atomic Absorption Spectrophotometer (AAS) which makes use of flame as the atomizer. In order to obtain accurate result, $100 \mathrm{ml}$ of sampled water were digested with $10 \mathrm{ml}$ concentrated nitric acid. The solution was heated for a period of 30 minutes, cooled and transferred to a 100 ml beaker which was filled up to $100 \mathrm{ml}$ mark with distilled water. 


\section{Calculation of Water Quality Index}

According to Verma et al., (2013), water quality index of a source of water supply is mostly calculated using the following equations:

$$
\begin{aligned}
& W Q I=\sum_{i=1}^{n} W_{i} \times Q_{i} \\
& W_{i}=\frac{K}{S_{i}} \\
& K=\left[\frac{1}{\sum_{n=i}^{n} \frac{1}{S_{i}}}\right] \\
& Q_{i}=\left[\frac{\left(V_{a}-V_{i}\right)}{\left(V_{s}-V_{i}\right)} \times 100\right]
\end{aligned}
$$

Where,

WQI = Water Quality Index

$\mathrm{Q}_{\mathrm{i}}=$ Quality rating

$\mathrm{W}_{\mathrm{n}}=$ Unit weight

$\mathrm{V}_{\mathrm{a}}=$ Measured value of water quality parameter

$\mathrm{V}_{\mathrm{i}}=$ Ideal value of the parameter. $(\mathrm{pH}=7$, other parameters $=0)$

$\mathrm{V}_{\mathrm{s}}=$ Standard value of the water quality parameter

$\mathrm{S}_{\mathrm{n}}=$ Acceptable value of water quality parameter from standards.

$\mathrm{K}=$ Proportionality constant

$\mathrm{S}_{\mathrm{i}}=$ Individual standard value for water quality parameter

$\mathrm{N}=$ number of parameters

Based on the water quality index, quality of groundwater supply from sampling points were categorized into unfit for drinking (> 100), very poor $(76-100)$, poor $(51-75)$, good $(26-50)$ and excellent $(0-25)$ (Oko et al., 2014). Turbidity, chloride, nitrate, $\mathrm{pH}$, hardness, total dissolved solids and electrical conductivity were the seven selected parameters used for water quality index.

\section{RESULTS}

\section{Rainy Season}

The mean temperature for the sampled wells during the rainy season was $27.48 \mathrm{oC}$, clearly above the guideline value of $25 \mathrm{oC}$. The $\mathrm{pH}$ of the water samples ranged from 5.6 to 8.5 and had a mean of 7.07 which was within the World Health Organization (WHO) guideline value of $6.5-8.5$. The mean electrical conductivity $(568.60 \mu \mathrm{S} / \mathrm{cm})$ was below the guideline value of $1,000 \mu \mathrm{S} / \mathrm{cm}$. The mean total dissolved solid $(330.57 \mathrm{mg} / \mathrm{l})$ was below the guideline value of $500 \mathrm{mg} / \mathrm{l}$. The mean value of chloride $(67.13 \mathrm{mg} / \mathrm{l})$ was below the guideline value of $250 \mathrm{mg} / 1$.

The mean total alkalinity $(120.57 \mathrm{mg} / \mathrm{l})$ was below the guideline value of $200 \mathrm{mg} / \mathrm{l}$. The mean total suspended solid $(180 \mathrm{mg} / \mathrm{l})$ was below the guideline value of $250 \mathrm{mg} / \mathrm{l}$. The mean turbidity (3.90 NTU) was below the guideline value of $5 \mathrm{NTU}$. The mean total hardness $(252.93 \mathrm{mg} / \mathrm{l})$ was above the guideline value of $150 \mathrm{mg} / \mathrm{l}$. The mean calcium $(98.27 \mathrm{mg} / \mathrm{l})$ was above the guideline value of $75 \mathrm{mg} / \mathrm{l}$. The mean magnesium $(1.91 \mathrm{mg} / \mathrm{l})$ was below the guideline value of $50 \mathrm{mg} / 1$.

The mean value of nitrate $(52.16 \mathrm{mg} / \mathrm{l})$ was above the standard value of $50 \mathrm{mg} / \mathrm{L}$. The mean value of sulphate (305.12 mg/l) was above the guideline value of $250 \mathrm{mg} / \mathrm{l}$. The mean value of phosphate $(1.76 \mathrm{mg} / \mathrm{l})$ was above the guideline value of $0.05 \mathrm{mg} / 1$. The mean value of iron $(0.16 \mathrm{mg} / \mathrm{l})$ was below the guideline value of $0.3 \mathrm{mg} / 1$.

The mean of lead $(0.01 \mathrm{mg} / \mathrm{l})$ was below the guideline value of $0.01 \mathrm{mg} / 1$ as shown in Table $2 \mathrm{a}$. The mean manganese $(0.03 \mathrm{mg} / 1)$ was below the guideline value of $0.4 \mathrm{mg} / 1$. The mean value of zinc $(0.03 \mathrm{mg} / \mathrm{l})$ was below the guideline value of $3.0 \mathrm{mg} / \mathrm{l}$. The mean cadmium $(0.02 \mathrm{mg} / \mathrm{l})$ was above the guideline value of $0.003 \mathrm{mg} / \mathrm{l}$. The mean chromium $(0.03 \mathrm{mg} / \mathrm{l})$ was below the guideline value of $0.05 \mathrm{mg} / \mathrm{l}$. The mean value of total coliform $(22.67 \times 10-4$ $\mathrm{CFU} / \mathrm{ml}$ ) was above the guideline value of $10 \mathrm{CFU} / \mathrm{ml}$. 


\section{Dry season}

The $\mathrm{pH}$ of the water samples had a mean value of 7.16 which was within the WHO guideline value of $6.5-8.5$ as shown in Table $2 \mathrm{~b}$. The mean temperature of the water samples $(16.20 \mathrm{oC})$ was below the guideline value of $25 \mathrm{oC}$. The mean electrical conductivity $(504.97 \mu \mathrm{S} / \mathrm{cm})$ was below the guideline value of $1,000 \mu \mathrm{S} / \mathrm{cm}$. The mean value of total dissolved solids $(308.3 \mathrm{mg} / \mathrm{l})$ was below the guideline value of $500 \mathrm{mg} / 1$ as shown in Table $2 \mathrm{~b}$.

The mean value of chloride $(68.44 \mathrm{mg} / \mathrm{l})$ was below the guideline value of $250 \mathrm{mg} / 1$. The mean total alkalinity (141.43 mg/l) was below the guideline value of $200 \mathrm{mg} / 1$. The mean total suspended solid (190 mg/1) was below the guideline value of $250 \mathrm{mg} / 1$. The mean turbidity (3.03 NTU) was below the guideline value of 5 NTU. The mean total hardness $(299.63 \mathrm{mg} / \mathrm{l})$ was above the guideline value of $150 \mathrm{mg} / \mathrm{l}$. The mean calcium (115.83 mg/l) was above the guideline value of $75 \mathrm{mg} / 1$.

Table 2a: Groundwater parameters mean against WHO values for rainy season

\begin{tabular}{|c|c|c|c|c|c|c|}
\hline SN & Parameter & $\mathrm{WHO}$ & Mean & $\begin{array}{l}\text { Standard } \\
\text { Error }\end{array}$ & $\begin{array}{l}\text { Standard } \\
\text { Dev. }\end{array}$ & $\begin{array}{l}\text { Coefficient of } \\
\text { Variation (\%) }\end{array}$ \\
\hline 1 & $\mathrm{pH}(-)$ & $6.5-8.5$ & 7.07 & \pm 0.114 & \pm 0.625 & 8.84 \\
\hline 2 & Temp $\left({ }^{\circ} \mathrm{C}\right)$ & 25 & 27.48 & \pm 0.261 & \pm 1.429 & 5.20 \\
\hline 3 & $\mathrm{EC}(\mu \mathrm{S} / \mathrm{cm})$ & 1000 & 568.60 & \pm 94.059 & \pm 515.180 & 90.61 \\
\hline 4 & $\operatorname{TDS}(\mathrm{mg} / \mathrm{l})$ & 500 & 330.57 & \pm 54.352 & \pm 297.701 & 90.06 \\
\hline 5 & T. Al. (mg/l) & 200 & 120.57 & \pm 15.927 & \pm 87.234 & 72.35 \\
\hline 6 & TSS (mg/1) & 250 & 180.00 & \pm 22.565 & \pm 123.596 & 68.66 \\
\hline 7 & Turb. (NTU) & 5 & 3.90 & \pm 0.379 & \pm 2.074 & 53.17 \\
\hline 8 & $\mathrm{TH}(\mathrm{mg} / \mathrm{l})$ & 150 & 252.93 & \pm 32.553 & \pm 178.298 & 70.49 \\
\hline 9 & $\mathrm{Ca}(\mathrm{mg} / \mathrm{l})$ & 75 & 98.27 & \pm 13.057 & \pm 71.518 & 72.78 \\
\hline 10 & $\mathrm{Mg}(\mathrm{mg} / \mathrm{l})$ & 50 & 1.91 & \pm 0.225 & \pm 1.230 & 64.51 \\
\hline 11 & $\mathrm{Cl}(\mathrm{mg} / \mathrm{l})$ & 250 & 67.13 & \pm 13.681 & \pm 74.936 & 111.63 \\
\hline 12 & $\mathrm{NO}_{3}{ }^{-}(\mathrm{mg} / \mathrm{l})$ & 50 & 52.16 & \pm 4.162 & \pm 22.796 & 43.70 \\
\hline 13 & $\mathrm{SO}_{4}{ }^{2-}(\mathrm{mg} / \mathrm{l})$ & 250 & 305.12 & \pm 17.511 & \pm 95.910 & 31.43 \\
\hline 14 & $\mathrm{PO}_{4}^{3-}(\mathrm{mg} / \mathrm{l})$ & 0.05 & 1.76 & \pm 0.178 & \pm 0.972 & 55.17 \\
\hline 15 & $\mathrm{Fe}(\mathrm{mg} / \mathrm{l})$ & 0.3 & 0.16 & \pm 0.006 & \pm 0.035 & 22.41 \\
\hline 16 & $\mathrm{~Pb}(\mathrm{mg} / 1)$ & 0.01 & 0.01 & \pm 0.000 & \pm 0.002 & 23.14 \\
\hline 17 & $\mathrm{Mn}(\mathrm{mg} / \mathrm{l})$ & 0.05 & 0.03 & \pm 0.001 & \pm 0.007 & 23.60 \\
\hline 18 & $\mathrm{Zn}(\mathrm{mg} / \mathrm{l})$ & 3.0 & 0.03 & \pm 0.002 & \pm 0.009 & 27.62 \\
\hline 19 & $\mathrm{Cd}(\mathrm{mg} / \mathrm{l})$ & 0.003 & 0.02 & \pm 0.001 & \pm 0.004 & 19.45 \\
\hline 20 & $\mathrm{Cr}(\mathrm{mg} / \mathrm{l})$ & 0.05 & 0.03 & \pm 0.002 & \pm 0.012 & 41.52 \\
\hline 21 & $\mathrm{TCC}(\mathrm{cfu} / \mathrm{ml}) \times 10^{-4}$ & 10 & 22.67 & \pm 4.555 & \pm 24.951 & 110.08 \\
\hline
\end{tabular}

Table 2b: Groundwater parameters mean against WHO values for dry season

\begin{tabular}{lllllll}
\hline SN & Parameter & WHO & Mean & $\begin{array}{l}\text { Standard } \\
\text { Error }\end{array}$ & $\begin{array}{l}\text { Standard } \\
\text { Dev. }\end{array}$ & $\begin{array}{l}\text { Coefficient of } \\
\text { Variation }(\%)\end{array}$ \\
\hline 1 & $\mathrm{pH}(-)$ & $6.5-8.5$ & 7.16 & \pm 0.210 & \pm 1.148 & 16.03 \\
2 & $\mathrm{Temp}\left({ }^{\circ} \mathrm{C}\right)$ & 25 & 16.20 & \pm 0.471 & \pm 2.578 & 15.91 \\
3 & $\mathrm{EC}(\mu \mathrm{s} / \mathrm{cm})$ & 1000 & 504.97 & \pm 80.224 & \pm 439.403 & 87.02 \\
4 & $\mathrm{TDS}(\mathrm{mg} / \mathrm{l})$ & 500 & 308.30 & \pm 49.234 & \pm 269.666 & 87.47 \\
5 & $\mathrm{~T} . \mathrm{Al} .(\mathrm{mg} / \mathrm{l})$ & 200 & 141.43 & \pm 13.442 & \pm 73.626 & 52.06 \\
6 & $\mathrm{TSS}(\mathrm{mg} / \mathrm{l})$ & 250 & 190.00 & \pm 24.377 & \pm 133.520 & 70.27 \\
7 & $\mathrm{Turb}(\mathrm{NTU})$ & 5 & 3.03 & \pm 0.373 & \pm 2.042 & 67.33 \\
8 & $\mathrm{TH}(\mathrm{mg} / \mathrm{l})$ & 150 & 299.63 & \pm 37.694 & \pm 206.458 & 68.90 \\
9 & $\mathrm{Ca}(\mathrm{mg} / \mathrm{l})$ & 75 & 115.83 & \pm 14.970 & \pm 81.996 & 70.79 \\
10 & $\mathrm{Mg}(\mathrm{mg} / \mathrm{l})$ & 50 & 2.32 & \pm 0.281 & \pm 1.540 & 66.43 \\
11 & $\mathrm{Cl}(\mathrm{mg} / \mathrm{l})$ & 250 & 68.44 & \pm 13.324 & \pm 72.981 & 106.63 \\
12 & $\mathrm{NO}{ }^{-}(\mathrm{mg} / \mathrm{l})$ & 50 & 48.29 & \pm 3.739 & \pm 20.481 & 42.41 \\
13 & $\mathrm{SO}_{4}{ }^{2-}(\mathrm{mg} / \mathrm{l})$ & 250 & 285.70 & \pm 17.540 & \pm 96.068 & 33.63 \\
14 & $\mathrm{PO}{ }^{3-}(\mathrm{mg} / \mathrm{l})$ & 0.05 & 1.71 & \pm 0.174 & \pm 0.954 & 55.95 \\
15 & $\mathrm{Fe}(\mathrm{mg} / \mathrm{l})$ & 0.3 & 0.19 & \pm 0.009 & \pm 0.048 & 25.18 \\
16 & $\mathrm{~Pb}(\mathrm{mg} / \mathrm{l})$ & 0.01 & 0.01 & \pm 0.000 & \pm 0.002 & 27.06 \\
\hline
\end{tabular}




\begin{tabular}{lllllll}
\hline 17 & $\mathrm{Mn}(\mathrm{mg} / \mathrm{l})$ & 0.05 & 0.03 & \pm 0.001 & \pm 0.008 & 23.02 \\
18 & $\mathrm{Zn}(\mathrm{mg} / \mathrm{l})$ & 3.0 & 0.03 & \pm 0.002 & \pm 0.008 & 24.83 \\
19 & $\mathrm{Cd}(\mathrm{mg} / \mathrm{l})$ & 0.003 & 0.02 & \pm 0.001 & \pm 0.004 & 19.95 \\
20 & $\mathrm{Cr}(\mathrm{mg} / \mathrm{l})$ & 0.05 & 0.03 & \pm 0.002 & \pm 0.012 & 39.49 \\
21 & $\mathrm{TCC}(\mathrm{cfu} / \mathrm{ml}) \times 10^{-4}$ & 10 & 6.63 & \pm 1.221 & \pm 6.688 & 100.82 \\
\hline
\end{tabular}

The mean magnesium ( $2.32 \mathrm{mg} / \mathrm{l})$ was below the guideline value of $50 \mathrm{mg} / 1$. The mean value of Nitrate $(48.29 \mathrm{mg} / \mathrm{l})$ was below the standard value of $50 \mathrm{mg} / 1$. The mean value of sulphate $(285.70 \mathrm{mg} / \mathrm{l})$ was above the guideline value of $250 \mathrm{mg} / \mathrm{l}$. The mean value of phosphate $(1.71 \mathrm{mg} / \mathrm{l})$ was above the guideline value of $0.05 \mathrm{mg} / \mathrm{l}$. The mean value of iron $(0.19 \mathrm{mg} / \mathrm{l})$ was below the guideline value of $0.3 \mathrm{mg} / \mathrm{l}$. The mean of lead $(0.01 \mathrm{mg} / \mathrm{l})$ was within the guideline value of $0.01 \mathrm{mg} / 1$. The mean manganese $(0.03 \mathrm{mg} / \mathrm{l})$ was below the guideline value of $0.05 \mathrm{mg} / \mathrm{l}$.

The mean value of zinc $(0.03 \mathrm{mg} / \mathrm{l})$ was below the guideline value of $3.0 \mathrm{mg} / \mathrm{l}$. The mean cadmium $(0.02 \mathrm{mg} / \mathrm{l})$ was above the guideline value of $0.003 \mathrm{mg} / \mathrm{l}$. The mean chromium $(0.03 \mathrm{mg} / \mathrm{l})$ was below the guideline value of 0.05 $\mathrm{mg} / \mathrm{l}$. The mean value of total coliform $(6.63 \times 10-4 \mathrm{CFU} / \mathrm{ml})$ was below the guideline value of $10 \mathrm{CFU} / \mathrm{ml}$.

\section{Discussion}

Results were compared with the acceptable limits of $\mathrm{WHO}$ and a few of the parameters were above the acceptable limits during the rainy and dry seasons. Total hardness, calcium, cadmium, sulphate and phosphate were the groundwater quality parameters having mean values above the standard values for both seasons. It can be observed that the groundwater in the study area is generally hard. This is beneficial in the aspect of health (Olutona et al., 2012). Although not economical, since hard water results in excessive use of soap for washing (Oko et al., 2014).

The application of water quality index was able to reveal the quality status of the sampled wells. Equations 2 and 3 were used to obtain the values for unit weight and the proportionality constant as shown in Table 3. Subsequently, standard values and the measured values of the water quality parameters were used to obtain the quality rating values applying equation 4 . These values for rainy and dry seasons were as shown in Tables 4 and 6 respectively.

Table 3: Water quality index independent variables

\begin{tabular}{lllll}
\hline S/N & Parameter & Standard Value $(\mathrm{Si})$ & Proportionality constant $(\mathrm{K})$ & Unit Weight (Wi) \\
\hline 1 & Chloride & 250 & 2.838 & 0.0114 \\
2 & Turbidity & 5 & 2.838 & 0.5676 \\
3 & Nitrate & 50 & 2.838 & 0.0568 \\
4 & pH & 8.5 & 2.838 & 0.3334 \\
5 & Hardness & 150 & 2.838 & 0.0189 \\
6 & Total Dissolved Solids & 500 & 2.838 & 0.0057 \\
7 & Electrical Conductivity & 1000 & 2.838 & 0.0028 \\
\hline
\end{tabular}

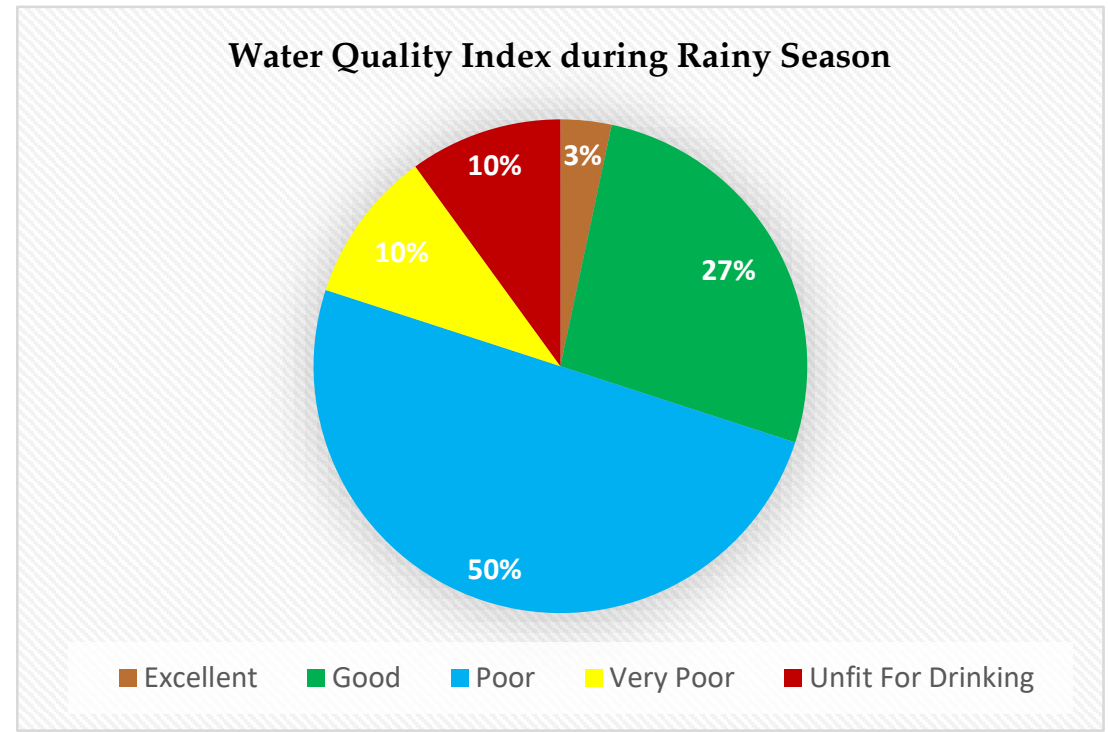

Figure 2: Water Quality Index for the Study Area during Rainy Season 


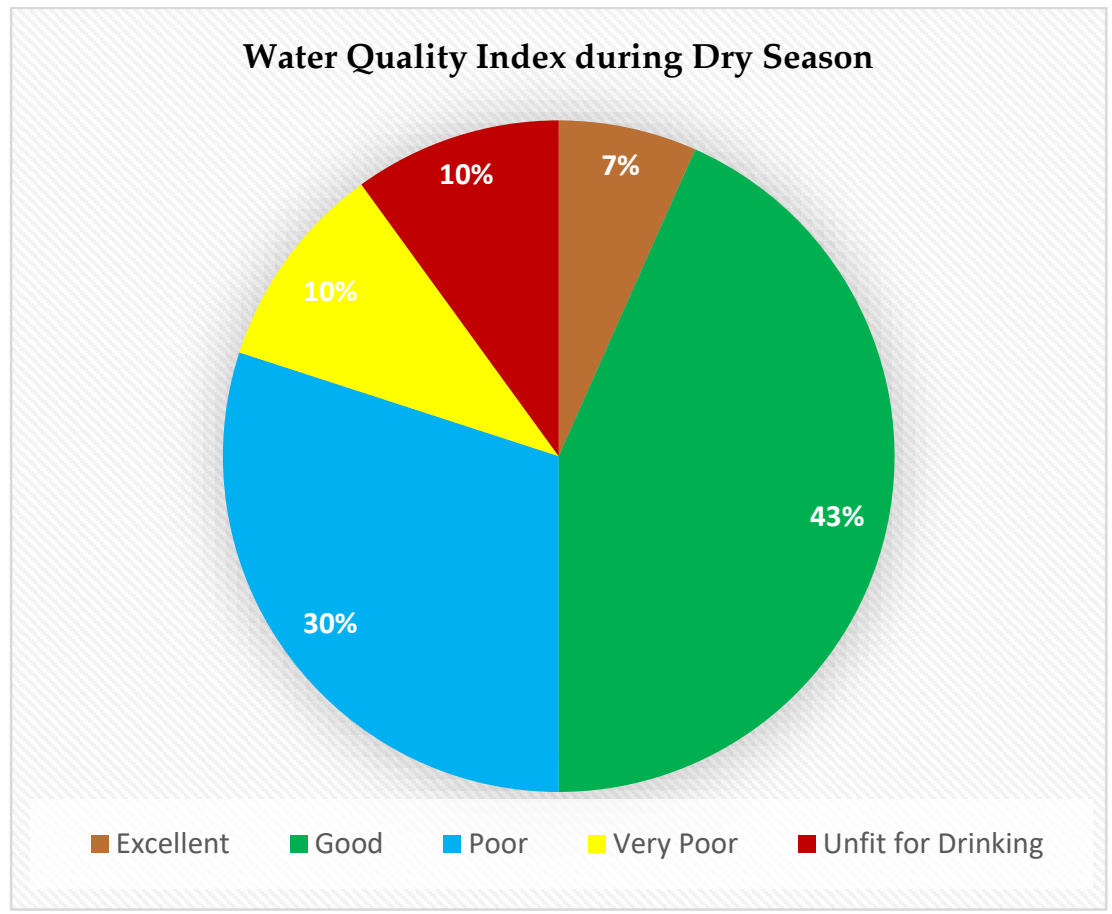

Figure 3: Water Quality Index for the Study Area during Dry Season

Table 4: Quality Rating Values for Seven Water Quality Parameters during Rainy Season

\begin{tabular}{|c|c|c|c|c|c|c|c|}
\hline Sample & $\mathrm{Cl}^{-}$ & Turb. & $\mathrm{NO}_{3}^{-}$ & $\mathrm{pH}$ & Hardness & TDS & EC \\
\hline $1 \mathrm{~A}$ & 0.16 & 0.6 & 0.9736 & 0.2 & 3.313 & 0.14 & 0.12 \\
\hline $1 \mathrm{~B}$ & 0.3696 & 0.2 & 0.8618 & 0.0 & 0.893 & 0.9 & 1.36 \\
\hline $2 \mathrm{~A}$ & 0.16 & 1.4 & 0.5576 & 0.4 & 0.740 & 0.12 & 0.086 \\
\hline $2 B$ & 0.19 & 0.8 & 1.0344 & 0.33 & 5.307 & 1.206 & 1.095 \\
\hline $3 \mathrm{~A}$ & 0.1260 & 0.8 & 0.9534 & 0.47 & 1.547 & 0.4 & 0.311 \\
\hline $3 B$ & 0.0820 & 0.2 & 1.2276 & 0.133 & 2.50 & 0.146 & 0.103 \\
\hline $4 \mathrm{~A}$ & 0.1220 & 1.0 & 1.2884 & 0.0 & 1.913 & 0.106 & 0.096 \\
\hline $4 \mathrm{~B}$ & 0.1520 & 0.8 & 1.8866 & 0.2 & 0.50 & 0.24 & 0.219 \\
\hline $5 \mathrm{~A}$ & 0.1220 & 0.8 & 1.1462 & 0.27 & 1.333 & 1.274 & 0.994 \\
\hline $5 B$ & 0.3619 & 0.2 & 0.4358 & 0.333 & 0.293 & 0.45 & 0.322 \\
\hline $6 \mathrm{~A}$ & 0.0820 & 0.4 & 1.024 & 0.066 & 2.387 & 1.120 & 1.020 \\
\hline $6 B$ & 1.1316 & 1.4 & 1.3084 & 0.333 & 1.913 & 0.480 & 1.036 \\
\hline $7 \mathrm{~A}$ & 0.5818 & 0.6 & 0.8924 & 0.933 & 0.3 & 1.22 & 0.957 \\
\hline $7 \mathrm{~B}$ & 0.4119 & 0.8 & 1.7852 & 0.333 & 0.360 & 0.958 & 0.684 \\
\hline $8 \mathrm{~A}$ & 0.1860 & 1.4 & 1.7344 & 1.000 & 1.573 & 1.688 & 1.319 \\
\hline $8 B$ & 0.5518 & 1.0 & 0.3344 & 0.0 & 0.747 & 2.020 & 1.430 \\
\hline $9 \mathrm{~A}$ & 0.0560 & 0.6 & 1.0144 & 0.867 & 4.287 & 2.026 & 1.843 \\
\hline $9 B$ & 0.5458 & 1.4 & 0.9428 & 0.267 & 1.027 & 0.116 & 0.090 \\
\hline $10 \mathrm{~A}$ & 0.1360 & 0.8 & 1.4404 & 0.533 & 1.78 & 0.63 & 0.45 \\
\hline 10B & 0.0900 & 1.0 & 0.3242 & 0.2 & 2.26 & 0.28 & 0.219 \\
\hline $11 \mathrm{~A}$ & 0.0820 & 0.4 & 0.4664 & 0.267 & 0.54 & 0.382 & 0.273 \\
\hline 11B & 0.0560 & 0.6 & 0.3648 & 0.40 & 0.52 & 0.30 & 0.196 \\
\hline $12 \mathrm{~A}$ & 0.0900 & 0.2 & 1.0444 & 0.2 & 2.14 & 0.28 & 0.257 \\
\hline $12 \mathrm{~B}$ & 1.2556 & 1.8 & 0.2838 & 0.533 & 1.167 & 1.66 & 1.284 \\
\hline $13 \mathrm{~A}$ & 0.0960 & 1.2 & 1.572 & 0.40 & 0.54 & 0.42 & 0.299 \\
\hline 13B & 0.0820 & 0.8 & 1.359 & 0.333 & 3.007 & 0.22 & 0.195 \\
\hline $14 \mathrm{~A}$ & 0.1620 & 0.6 & 1.041 & 0.067 & 1.807 & 0.4 & 0.295 \\
\hline 14B & 0.0720 & 0.4 & 1.2698 & 0.267 & 1.513 & 0.28 & 0.215 \\
\hline $15 \mathrm{~A}$ & 0.0620 & 0.8 & 1.0152 & 0.267 & 1.993 & 0.148 & 0.115 \\
\hline 15B & 0.4798 & 0.4 & 1.7144 & 0.333 & 2.387 & 0.224 & 0.175 \\
\hline
\end{tabular}


The Water Quality Index (WQI) values showed that 30\% of the selected groundwater sources were adequate for consumption while $50 \%$ were poor, $10 \%$ were very poor and $10 \%$ were unfit for drinking during rainy season as shown in Figure 2. The Water Quality Index (WQI) values showed that 50\% of the selected groundwater sources were adequate for consumption while $30 \%$ were poor, $10 \%$ were very poor and $10 \%$ were unfit for drinking during the dry season as shown in Figure 3. It can be observed that the water quality was better during the dry season than the rainy season.

Table 5: Water Quality Index for Seven Water Quality Parameters during Rainy Season

\begin{tabular}{|c|c|c|c|c|c|c|c|c|}
\hline Sample & $\begin{array}{l}\mathrm{Cl}^{-} \\
1\end{array}$ & $\begin{array}{l}\text { Turb. } \\
2\end{array}$ & $\begin{array}{l}\mathrm{NO}_{3}{ }^{-} \\
3\end{array}$ & $\begin{array}{l}\mathrm{pH} \\
4\end{array}$ & $\begin{array}{l}\text { Hardness } \\
5\end{array}$ & $\begin{array}{l}\text { TDS } \\
6\end{array}$ & $\begin{array}{l}\text { EC } \\
7\end{array}$ & $\begin{array}{l}\text { Total } \\
(1+2+3+4+5+6+7)\end{array}$ \\
\hline $1 \mathrm{~A}$ & 0.1824 & 34.056 & 5.530 & 6.668 & 5.262 & 0.0798 & 0.1736 & 51.95 \\
\hline 1B & 0.4213 & 11.352 & 4.395 & 0.0 & 1.688 & 0.513 & 0.3808 & 18.75 \\
\hline $2 \mathrm{~A}$ & 0.1824 & 79.464 & 3.167 & 13.336 & 1.3986 & 0.0684 & 0.0241 & 97.6405 \\
\hline 2B & 0.2166 & 45.408 & 5.375 & 11.002 & 10.030 & 0.6874 & 0.3066 & 73.026 \\
\hline $3 \mathrm{~A}$ & 0.1436 & 45.408 & 5.415 & 15.670 & 2.924 & 0.228 & 0.087 & 59.876 \\
\hline 3B & 0.0935 & 11.352 & 6.3728 & 4.434 & 4.725 & 0.0832 & 0.0288 & 27.0893 \\
\hline $4 \mathrm{~A}$ & 0.1391 & 56.76 & 7.3181 & 0.0 & 3.6156 & 0.06042 & 0.02688 & 57.9201 \\
\hline $4 \mathrm{~B}$ & 0.1733 & 45.408 & 10.7159 & 6.668 & 0.945 & 0.1368 & 0.06132 & 64.108 \\
\hline $5 \mathrm{~A}$ & 0.1391 & 45.408 & 6.5104 & 9.0018 & 2.5194 & 0.7262 & 0.27832 & 64.583 \\
\hline $5 B$ & 0.4126 & 11.352 & 2.4753 & 11.102 & 0.5538 & 0.2565 & 0.0902 & 26.2424 \\
\hline $6 \mathrm{~A}$ & 0.0935 & 22.704 & 5.8163 & 2.2004 & 4.5114 & 0.6384 & 0.2556 & 36.2496 \\
\hline $6 \mathrm{~B}$ & 1.29 & 79.464 & 7.432 & 11.102 & 3.6156 & 0.2736 & 0.2901 & 103.467 \\
\hline $7 \mathrm{~A}$ & 0.5633 & 34.056 & 5.0688 & 31.126 & 0.567 & 0.6954 & 0.2680 & 72.345 \\
\hline $7 \mathrm{~B}$ & 0.4696 & 45.408 & 10.140 & 11.102 & 0.6804 & 0.5461 & 0.1915 & 58.5376 \\
\hline $8 \mathrm{~A}$ & 0.21204 & 79.464 & 9.3514 & 33.34 & 2.973 & 0.9622 & 0.3693 & 125.67 \\
\hline $8 \mathrm{~B}$ & 0.5291 & 56.76 & 1.3994 & 0.000 & 1.4118 & 1.1514 & 0.4004 & 61.6521 \\
\hline 9A & 0.0638 & 34.056 & 5.7618 & 23.9058 & 3.1024 & 1.1548 & 0.5160 & 63.5607 \\
\hline 9B & 0.5222 & 79.4640 & 5.3551 & 3.9018 & 1.9410 & 0.0661 & 0.0252 & 91.2754 \\
\hline $10 \mathrm{~A}$ & 0.1550 & 45.408 & 8.1815 & 17.770 & 3.3642 & 0.3591 & 0.126 & 75.3638 \\
\hline 10B & 0.1026 & 56.76 & 1.3415 & 6.668 & 4.2714 & 0.1596 & 0.0613 & 63.364 \\
\hline $11 \mathrm{~A}$ & 0.0935 & 32.704 & 2.5492 & 3.9018 & 1.0206 & 0.2177 & 0.0764 & 30.563 \\
\hline $11 B$ & 0.0638 & 34.056 & 2.0721 & 13.3360 & 0.9828 & 0.171 & 0.0549 & 50.7366 \\
\hline $12 \mathrm{~A}$ & 0.1026 & 11.352 & 5.3322 & 6.668 & 4.0446 & 0.1596 & 0.0720 & 27.731 \\
\hline $12 \mathrm{~B}$ & 1.4314 & 102.168 & 1.5120 & 12.7702 & 2.2056 & 0.9462 & 0.3595 & 121.393 \\
\hline $13 \mathrm{~A}$ & 0.1094 & 68.112 & 3.929 & 13.336 & 1.0206 & 0.2394 & 0.0837 & 86.5271 \\
\hline $13 B$ & 0.0935 & 45.408 & 0.7191 & 11.102 & 5.6832 & 0.1254 & 0.0546 & 53.1858 \\
\hline $14 \mathrm{~A}$ & 0.1847 & 34.056 & 5.9129 & 2.2338 & 3.4152 & 0.228 & 0.0826 & 45.113 \\
\hline 14B & 0.0821 & 22.704 & 7.2125 & 3.9018 & 2.8596 & 0.1596 & 0.0602 & 35.9798 \\
\hline $15 \mathrm{~A}$ & 0.0707 & 45.408 & 5.7663 & 3.9018 & 3.7668 & 0.0844 & 0.0322 & 53.0302 \\
\hline 15B & 0.5470 & 22.7040 & 9.7378 & 11.102 & 4.5114 & 0.1277 & 0.049 & 43.779 \\
\hline
\end{tabular}

For the rainy season, samples $6 \mathrm{~B}, 8 \mathrm{~A}$ and $12 \mathrm{~B}$ had water quality index greater than 100 as shown in Table 5 . For the dry season, samples $8 \mathrm{~A}, 9 \mathrm{~A}$ and $13 \mathrm{~A}$ had water quality index greater than 100 as shown in Table 7 . It can be observed that the water sample labelled $8 \mathrm{~A}$ was unfit for drinking throughout the season. Groundwater from these five locations in the study area should be subjected to conventional treatment in order to safeguard the health of the populace that demand water from such wells (Ogunbode et al., 2016). 
Table 6: Quality Rating Values for Seven Water Quality Parameters during Dry Season

\begin{tabular}{llllllll}
\hline Sample & $\mathrm{Cl}^{-}$ & Turb. & $\mathbf{N O}^{-}$ & $\mathbf{p H}$ & Hardness & TDS & EC \\
\hline 1A & 0.1700 & 0.4000 & 0.9444 & 0.3333 & 3.5667 & 0.1540 & 0.1400 \\
1B & 0.3898 & 0.4000 & 0.8188 & 0.7333 & 0.6667 & 1.2100 & 1.008 \\
2A & 0.1500 & 1.2000 & 0.5520 & 0.6000 & 1.1000 & 0.0760 & 0.0590 \\
2B & 0.1900 & 0.6000 & 1.0138 & 0.5333 & 6.4267 & 1.3520 & 0.9650 \\
3A & 0.1660 & 0.4000 & 0.9152 & 0.0000 & 1.9400 & 0.3000 & 0.2720 \\
3B & 0.0800 & 0.4000 & 1.1908 & 0.8660 & 2.6733 & 0.1320 & 0.1100 \\
4A & 0.1200 & 0.2000 & 1.2240 & 0.9333 & 2.1067 & 0.0660 & 0.0510 \\
4B & 0.1500 & 0.4000 & 1.6678 & 0.1333 & 0.7533 & 0.2520 & 0.1800 \\
5A & 0.1220 & 1.0000 & 1.0086 & 0.4000 & 1.6200 & 0.9840 & 0.8940 \\
5B & 0.3399 & 0.2000 & 0.4270 & 0.2000 & 0.3667 & 0.2720 & 0.2260 \\
6A & 0.0860 & 0.2000 & 0.9830 & 0.4667 & 2.5533 & 1.2480 & 0.9600 \\
6B & 1.1616 & 0.2000 & 1.2430 & 0.3333 & 2.1000 & 1.0820 & 0.7730 \\
7A & 0.6858 & 0.6000 & 0.8032 & 1.0000 & 0.4467 & 0.9360 & 0.8500 \\
7B & 0.4199 & 1.0000 & 1.6602 & 0.4667 & 0.4333 & 0.6860 & 0.5920 \\
8A & 0.1979 & 1.4000 & 1.4742 & 2.3333 & 1.9733 & 1.5500 & 1.2760 \\
8B & 0.5617 & 1.2000 & 0.2942 & 0.7333 & 0.8000 & 1.4700 & 1.1300 \\
9A & 0.0500 & 0.4000 & 0.9840 & 2.0000 & 4.7200 & 1.7760 & 1.6150 \\
9B & 0.5018 & 1.0000 & 0.8956 & 1.0000 & 1.5133 & 0.0960 & 0.0820 \\
10A & 0.1260 & 0.4000 & 1.3684 & 0.2667 & 2.4867 & 0.5120 & 0.4190 \\
10B & 0.0860 & 0.2000 & 0.3210 & 0.0000 & 2.4933 & 0.2540 & 0.1960 \\
11A & 0.0780 & 1.0000 & 0.4570 & 0.2000 & 0.5733 & 0.2420 & 0.2190 \\
11B & 0.0600 & 0.4000 & 0.3502 & 0.6667 & 0.5800 & 0.1880 & 0.1620 \\
12A & 0.0920 & 0.2000 & 1.0130 & 0.8000 & 3.2000 & 0.3080 & 0.2530 \\
12B & 0.9277 & 0.8000 & 0.2554 & 0.2667 & 1.4200 & 1.5060 & 1.1590 \\
13A & 0.0980 & 1.6000 & 1.4934 & 0.1333 & 0.5267 & 0.3960 & 0.3600 \\
13B & 0.0560 & 0.2000 & 1.0454 & 0.2000 & 3.2267 & 0.4300 & 0.3700 \\
14A & 0.1660 & 0.6000 & 0.9682 & 0.2000 & 1.9933 & 0.1980 & 0.1630 \\
14B & 0.0620 & 1.0000 & 1.0794 & 0.2667 & 2.2667 & 0.5460 & 0.4200 \\
15A & 0.0740 & 0.4000 & 0.8934 & 0.0000 & 2.4067 & 0.1420 & 0.1290 \\
15B & 0.8457 & 0.2000 & 1.6286 & 0.4667 & 2.9933 & 0.1340 & 0.1160 \\
\hline & & & & & & &
\end{tabular}

Table 7: Water Quality Index for Seven Water Quality Parameters during Dry Season

\begin{tabular}{|c|c|c|c|c|c|c|c|c|}
\hline Sample & $\begin{array}{l}\mathrm{Cl}^{-} \\
1\end{array}$ & $\begin{array}{l}\text { Turb. } \\
2\end{array}$ & $\begin{array}{l}\mathrm{NO}_{3}^{-} \\
3\end{array}$ & $\begin{array}{l}\mathrm{pH} \\
4\end{array}$ & $\begin{array}{l}\text { Hardness } \\
5\end{array}$ & $\begin{array}{l}\text { TDS } \\
6\end{array}$ & $\begin{array}{l}\text { EC } \\
7\end{array}$ & $\begin{array}{l}\text { Total } \\
(1+2+3+4+5+6+7)\end{array}$ \\
\hline $1 \mathrm{~A}$ & 0.1938 & 22.7040 & 5.3642 & 11.1122 & 6.7411 & 0.0878 & 0.0392 & 46.2423 \\
\hline 1B & 0.4444 & 22.7040 & 4.5508 & 24.4482 & 1.2601 & 0.6897 & 0.2822 & 54.3794 \\
\hline $2 \mathrm{~A}$ & 0.1710 & 68.1120 & 3.1354 & 20.0040 & 2.0790 & 0.0433 & 0.0165 & 93.5612 \\
\hline $2 \mathrm{~B}$ & 0.2166 & 34.0560 & 5.7584 & 17.7802 & 12.1465 & 0.7706 & 0.2702 & 70.9985 \\
\hline $3 \mathrm{~A}$ & 0.1892 & 22.7040 & 5.1983 & 0.0000 & 3.6666 & 0.1710 & 0.0762 & 32.0053 \\
\hline 3B & 0.0912 & 22.7040 & 1.0837 & 23.8724 & 5.0525 & 0.0752 & 0.0308 & 52.9098 \\
\hline $4 \mathrm{~A}$ & 0.1368 & 11.3520 & 5.9523 & 31.1162 & 3.3817 & 0.0376 & 0.0143 & 51.9909 \\
\hline 4B & 0.1710 & 22.7040 & 9.4731 & 4.4442 & 1.4237 & 0.1436 & 0.0504 & 38.4100 \\
\hline $5 \mathrm{~A}$ & 0.1391 & 56.7600 & 5.7289 & 13.3360 & 3.0618 & 0.5609 & 0.2503 & 79.8370 \\
\hline $5 B$ & 0.3875 & 11.3520 & 2.4254 & 6.6680 & 0.5931 & 0.1550 & 0.0633 & 14.3037 \\
\hline $6 \mathrm{~A}$ & 0.0980 & 11.3520 & 5.5834 & 15.5598 & 4.3257 & 0.7114 & 0.2688 & 37.8991 \\
\hline 6B & 1.3242 & 11.3520 & 7.0602 & 11.1122 & 3.9790 & 0.6167 & 0.2164 & 35.6507 \\
\hline 7A & 0.7818 & 34.0560 & 4.5622 & 33.3400 & 0.3443 & 0.5335 & 0.2380 & 73.8558 \\
\hline 7B & 0.4787 & 56.7600 & 9.4299 & 15.5598 & 0.3189 & 0.3910 & 0.1658 & 33.1041 \\
\hline $8 \mathrm{~A}$ & 0.2256 & 79.4640 & 8.3735 & 77.7900 & 3.7295 & 0.8835 & 0.3573 & 170.8234 \\
\hline $8 \mathrm{~B}$ & 0.5403 & 68.1120 & 1.5711 & 24.4482 & 1.5120 & 0.8379 & 0.3164 & 37.3379 \\
\hline 9A & 0.0570 & 22.7040 & 5.5891 & 66.6800 & 8.9208 & 1.0123 & 0.4522 & 105.4154 \\
\hline 9B & 0.5721 & 56.7600 & 5.0870 & 33.3400 & 2.3601 & 0.0547 & 0.0230 & 38.1969 \\
\hline $10 \mathrm{~A}$ & 0.1436 & 22.7040 & 7.7725 & 8.3918 & 4.5999 & 0.2918 & 0.1173 & 44.0209 \\
\hline 10B & 0.0980 & 11.3520 & 1.8233 & 0.0000 & 4.7123 & 0.1448 & 0.0549 & 18.1853 \\
\hline
\end{tabular}




\begin{tabular}{lllllllll}
\hline 11A & 0.0889 & 56.7600 & 2.5958 & 6.6680 & 1.0835 & 0.1379 & 0.0613 & 57.3954 \\
11B & 0.0684 & 22.7040 & 1.9890 & 22.2278 & 1.0962 & 0.1072 & 0.0454 & 48.2380 \\
12A & 0.1049 & 11.3520 & 5.7538 & 26.6720 & 6.0480 & 0.1756 & 0.0708 & 50.1771 \\
12B & 1.0576 & 45.4080 & 1.4507 & 8.3918 & 2.6838 & 0.8584 & 0.3245 & 50.1748 \\
13A & 0.1117 & 90.8160 & 8.4825 & 4.4442 & 0.3955 & 0.2257 & 0.1008 & $\mathbf{1 0 4 . 5 7 6 4}$ \\
13B & 0.0638 & 11.3520 & 5.3379 & 6.6680 & 6.0985 & 0.2451 & 0.1036 & 29.8689 \\
14A & 0.1892 & 34.0560 & 5.4994 & 6.6680 & 3.7673 & 0.1129 & 0.0456 & 50.3384 \\
14B & 0.0707 & 56.7600 & 6.1310 & 8.3918 & 4.2841 & 0.3112 & 0.1176 & 76.0664 \\
15A & 0.0844 & 22.7040 & 5.0745 & 0.0000 & 4.5487 & 0.0809 & 0.0361 & 32.5286 \\
15B & 0.3641 & 11.3520 & 9.2505 & 15.5598 & 5.5573 & 0.0764 & 0.0325 & 42.1926 \\
\hline
\end{tabular}

\section{CONCLUSION}

Five out of the thirty sampled groundwater sources were confirmed unfit for drinking during both rainy and dry seasons. These were based on the results from the water quality index, which is useful for effective management by the societal policymakers (Acharya et al., 2018). These wells had water quality index greater than 100 (Oko et al., 2014). These wells should be subjected to water treatment processes, such as that used in Obafemi Awolowo University ozonized bottled water production system (Oladepo et al., 2012). While others were either poor or good for drinking, which can be subjected to slight or no conventional treatment respectively.

Water supply for domestic and industrial use should be free from disease-causing organisms and other matters which are unacceptable to the final consumers (Ayodele and Olufunmilayo, 2012a). Therefore, periodical assessment of physical, chemical and microbial analysis of groundwater in Iwo Local Government Area is recommended. This assessment will aid early identification of any potential future degradation of the groundwater parameters which were below and within the acceptable limits. There should be frequent public awareness by the local government officials about the role of individuals to protect groundwater from residential, agricultural and industrial waste contaminations.

\section{REFERENCES}

Acharya, S., Sharma, S. K., and Khandegar, V. (2018). Assessment of groundwater quality by Water Quality Indices for Irrigation and drinking in South West Delhi, India. Data in Brief, 18(June 2018), 2019-2028.

Adegbola, A. A., and Adewoye, A. O. (2012). On Investigating Pollution of Groundwater from Atenda Abattoir Wastes, Ogbomoso, Nigeria. International Journal of Engineering and Technology, 2(9), 1-17.

Ahmed, S. S. (2017). Assessment of Groundwater Quality Parameters Using Multivariate Statistics- A Case Study of Majmaah, KSA. International Journal of Environmental Monitoring and Analysis, 5(2), 32-40.

Atobatele, E. O., and Olutona, G. O. (2013). Spatio-seasonal physico-chemistry of Aiba stream, Iwo, Nigeria. African Journal of Biotechnology, 12(14), 1630-1635.

Ayodele, A., and Olufunmilayo, A. (2012). Impact Assessment of Selected Pollution Sources on Groundwater Quality in Wells in Gambari Community, Ogbomoso, Nigeria. International Journal of Modern Engineering Research, 2(5), 3118-3122.

Dohare, D., Deshpande, S., and Kotiya, A. (2014). Analysis of Ground Water Quality Parameters : A Review. Research Journal of Engineering Sciences, 3(5), 26-31.

Herojeet, R., Rishi, M. S., Lata, R., and Sharma, R. (2016). Application of environmetrics statistical models and water quality index for groundwater quality characterization of alluvial aquifer of Nalagarh Valley, Himachal Pradesh, India. Sustainable Water Resources Management, 2(1), 39-53.

Jeje, J. O., and Oladepo, K. T. (2014). Assessment of Heavy Metals of Boreholes and Hand Dug Wells in Ife North Local Government Area of Osun State, Nigeria. International Journal of Science and Technology, 3(4), 209-214.

Mahapatra, S. S., Sahu, M., Patel, R. K., and Panda, B. N. (2012). Prediction of Water Quality Using Principal Component Analysis. Water Qual Expo Health, 4, 93-104.

Munna, G., Nury, A. H., Islam, S., and Rahman, H. (2015). Spatial Distribution Analysis and Mapping of Groundwater Quality Parameters for the Sylhet City Corporation (SCC) Area Using GIS. Hydrology, 3(1), 1-10.

Nas, B. (2009). Geostatistical Approach to Assessment of Spatial Distribution of Groundwater Quality. Polish J. of Environ. Stud., 18(6), 1073-1082. 
National Population Commission, N. (2006): Population Census Figure.

Ogunbode, T. O., Akintunde, E. A., and Akinola, O. T. (2016). Assessment of underground water quality and pollution sources apportionment in a growing urban centre in Osun State South Western Nigeria. European Journal of Geography, 7(3), 71-85.

Oko, O. J., Aremu, M. O., Odoh, R., Yebpella, G., and Shenge, G. A. (2014). Assessment of Water Quality Index of Borehole and Well Water in Wukari Town, Taraba State, Nigeria. Journal of Environmental and Earth Science, $4(5), 1-9$.

Oladepo, K. T., Jeje, J. O., Ogedengbe, M. O., and Fadipe, O. O. (2012). Technical Assessment of a University-Based Ozone-Treated Bottled Water Production System. Transnational Journal of Science and Technology, 2(9), 31-46.

Olutona, G. O., Akintunde, E. A., and Otolorin, J. A. (2012). Physico-chemical quality assessment of shallow wellwaters in Iwo, southwestern Nigeria. Journal of Environmental Science and Water Resources, 1(6), 127-132.

Sharma, S., and Chhipa, R. C. (2013). Interpretation of ground water quality parameter for selected area of Jaipur using regression and correlation analysis. Journal of Scientific $\mathcal{E}$ Industrial Research, 72(December), 781-783.

Verma, A., Thakur, B., Katiyar, S., Singh, D., and Rai, M. (2013). Evaluation of ground water quality in Lucknow, Uttar Pradesh using remote sensing and geographic information systems (GIS). International Journal of Water Resources and Environmental Engineering, 5(2), 67-76.

WHO. (2017): Guidelines for drinking water quality: fourth edition incorporating the first addendum. Geneva.

$--0--$ 